\title{
Numerical Analysis of Patrol Boat Performance with a Stern Flap
}

\author{
Edi Jadmiko', Sunarsih ${ }^{2}$, Jayanti Wulandari ${ }^{3}$ \\ (Received: 01 August 2019 / Revised: 18 June 2020 / Accepted: 29 June 2020)
}

\begin{abstract}
Past researches revealed that installation of a stern flap reduces the value by $5 \%$ to $10 \%$. The current research investigates resistance reduction on a patrol boat due to variation of the flap span width and angle of installation. The flap chord length was varied by $50 \%$ and $100 \%$ of the ship transom width (BT) whilst the installation angle was set to $0^{0}$ and $5^{0}$. Numerical tests were carried out using CFD method employing NUMECA Fine Marine software. Simulation result disclosed that the stern flap length of $50 \%$ BT installed at $0^{0}$ indicates the most optimum arrangement. Reduction of the resistance value increases correspondingly to the ship resistance as the ship speed increases. The wave form developed conforms with the flap width such that the wider the flap results in wider wave form. A reduction at the most of $1.87 \%$ was yielded at $15 \mathrm{knot}$ ship speed. No significant reduction was observed due to installation angle at $0^{0}$ and $5^{0}$.
\end{abstract}

Keywords_-NUMECA fine marine, resistance reduction, stern flap installation, waveform.

\section{INTRODUCTION}

$\mathrm{P}$ atrol boat is a ship that serves as an operational support in the field of defense and security. For that the ship must have a high speed, to support the operational of the ship. The ship moves at a certain speed through the fluid water, this causes the ship to experience resistance. Reducing the value of the resistance on the ship can be done by adding stern flap or the addition of the stern of the ship. From journal, it was explained that with the addition of stern flap, it was able to reduce the resistance of the ship by $5-10 \%$, compared to the rudder bulbows which only reduce the resistance value by $2-3 \%$ [1].

In this study numerical test was conducted to determine the effect of adding stern flaps on patrol boats by looking at the shape of the flow produced. The variation used in the stern flap are variations in the flap width of $100 \% \mathrm{BT}$ and $50 \% \mathrm{BT}$, for variations in the angle used at $0^{0}$ and $5^{0}$. In this study the test were carried out using 3 speeds, speeds of 10 knots, 13 knots, and 15 knots Test was done by using NUMECA Fine Marine software with the Computational Fluid Dynamic. In this study it is expected that the addition of angular variations can reduce the value of the greater resistance on the ship.

\section{A. Patrol Boat}

Patrol boats are operational support in the defense and security sector [2]. Patrol boats are naval vessels designed for defense. They are commonly found in border protection, smuggling, piracy [3]. In the discussion of the final task used is the type of planning hull. Planning hull is type of hull $\mathrm{V}$ that have a double at

Edi Jadmiko is with Departement of Marine Engineering, Institut Teknologi Sepuluh Nopember, Surabaya, 60111, Indonesia. E-mail: e.djatmiko@yahoo.com

Sunarsih is with Departement of Marine Engineering, Institut Teknologi Sepuluh Nopember, Surabaya, 60111, Indonesia. E-mail: sunarsihits@gmail.com

Jayanti Wulandari is with Departement of Marine Engineering, Institut Teknologi Sepuluh Nopember, Surabaya, 60111, Indonesia. Email: jayantiwulandari4@gmail.com bilga [4]. High speed planning hull is used to reduce negative pressure on the hull when the ship reaches high speeds.

\section{B. Flow Characteristics}

Fluid flow is characterised into two groups [5].

1) Laminar - a fluid flow that moves and has a layer of layer that forms the flow line and does not intersect with each other

2) Turbulent - a flow that has a relatively large flow velocity and the motion of particles is irregular with each other

\section{Froude Number}

Froude Number is a number used to measure resistance from object that move through water and compare object of different size [6].

$F n=\frac{V}{\sqrt{g L}}$ or $F n=\frac{V}{\sqrt{g D}}$

where

$$
\begin{array}{ll}
\text { Fn } & : \text { Froude Number } \\
\text { V } & : \text { Flow Velocity } \\
\text { D } & : \text { A } / T
\end{array}
$$

So to state the magnitude of the form resistance or residual resistance can use Froudes Number (Fn) which is influence by speed (v), grafity $(\mathrm{g})$, and length of ship (L) [7]

\section{Ship Stern}

The stern of the ship is the back of the ship, and there are several controlling components including rudder, propeller, and other. Ship resistance is the same as force and because it is produced by water, this is called a hysdrodynamic force [8]. The shape and type of stern deopends on the type of steering installed [9]. In the past the stern which was widely used on ships was counter or eliptic stern, but along with the many developed stern forms that are widely used now on ships are cruiser or transoms. The cruiser stern type is considered to have a good shape, and also provides hydrodynamic usability that can minimize the value of the resistance on the part 
of the ship below the water line [10]. The shape of the stern flap and stern wedge on the ship can reduce viscous pressure resistance and can also reduce the resistance that occurs on the ship [11].

\section{E. Ship Resistance}

Ship resistance is the study of fluid reactions due to the movement of ships through the fluid. The resistance is the same as the force component which works parallel to the axis of the ship speed of movement [12]. The total value of the total resistance on the ship is the total number of resistance working on the ship as follow [13].

1) Friction Resistance - a resistance that is received by the ship when driving which result from friction between the skin of the hull of the ship and water.

2) Wave Resistance - the loss of energy caused by waves when the bow of the ship hits the water

3) Additional Resistance - the pressure caused by addition resistance to wave resistance and friction resistance

\section{F. Advantages of Stern Flap}

Stern flap is the addition of the hull length of the ship after transom in the base plate form [14]. Important parameters of stern flap are flap length, flap width, and flap angle along the transom. Stern flap has the effect of the performance of a ship like a stern wedge. All stern flaps depend on the type and size of the vessel used [15]. On the planning hull stern flap the effect of the trim angle is $4-5^{0}$. The basic advantage of adding a stern flap is the change in flow around the propeller. This flow provides reduce drag on the stern and changes the wave resistance on the ship [16]. Stern flap result in a decrease in the flow of the hull in the location of the length of the addition. The decrease in flow velocity will increase the pressure on the hull, this causes drag reduction. The advantages of adding a stern flap are as follows.

1) Reducing powering resistance. Research shows a reduction in resistance due to the addition of a stern flap of $5-10 \%$

2) Increase maximum speed

3) Change the transom wave system

\section{G. Hydrodynamic Effect on Stern Flaps}

Installation of the stern flap on the ship creates a hydrodynamic effect on the ship. The hydrodynamic effect that are added include changes in the wave system, changes in stern flow, and lift as shown by Figure 1. The following will be explained about the hydrodynamic effect caused by the installation of a stern flap [17].
1) Wave System Changes

At the same speed the stern flap result in reduced flow areas: height, slop, and waves. With the presence of a stern flap it can reduce wave height in the wave system near the stern area and far from the stern

2) Change of Stern Flow

Stern Flap reduced flow speed and increases dynamic pressure under the hull of the ship. Increasing the pressure area causes a greater lift which results in a positive effect on the direction of the ship. Stern flap increases the speed of outflow on the trailing edge compared to transom without flap. This increase in speed will reduce the flow rate and make the separation flow in a reduction in the viscous pressure in a reduction in the viscous pressure resistance.

3) Lift and Drag

Stern flap can produce lift and drag at all speed and conditions. The advantages is the interaction with the hull and propeller so that it can reduce vessel resistance. Lifting forces and drag increase more as the chord, span, and angle of the flap increase

\section{H. Computational Fluid Dynamic}

It is a calculation method with a control of dimensions, area, and volume by utilizing computer assistance to perform calculations on each element of the division [18]. The initial of the equation is boundary condition. Boundary condition is a condition where calculation controls are defined as the initial definition which will be involved in the calculation controls and adjacent to it through equations [19]. In general, the calculation process in the CFD method consist of 3 main part, preprocessor, processor/solver, postprocessor.

\section{NUMECA Fine Marine}

NUMECA is a trademark of an international company providing NUMECA international CFD processing software. NUMECA has product for design processors and meshing and solvers for CFD processing software [20].

\section{METHOD}

\section{A. Ship Modeling using Maxsurf and NUMECA Fine} Marine

The patrol ship model was made based on the existing lines plan of the real ship. Modeling was done in two

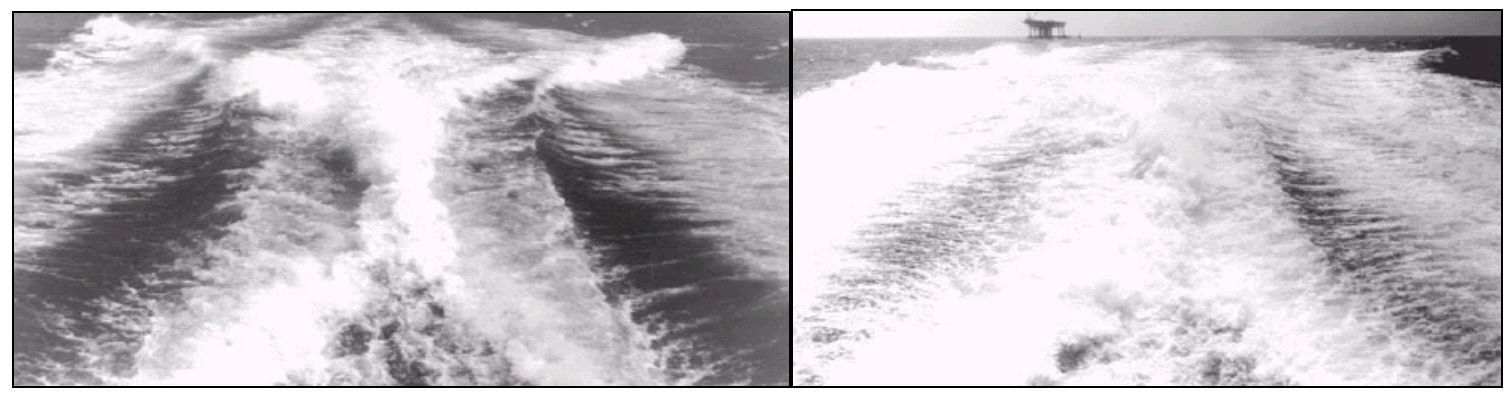

Figure. 1. Wave flow without (left) and with stern flap (right). 
steps. Firstly, the surface model was made using Maxsurf software then solidified using NUMECA Fine Marine. Figure 2 displayed the patrol boat model obtained.

\section{B. Model Verification}

Verification was performed to check the correctness of the initial model made prior to any further modification. Ship resistance was chosen as variable for verification and two resistance values originated from numerical simulations using Maxsurf and NUMECA Fine Marine software was used for comparison.

\section{Ship Modeling with Stern Flap}

The research focuses on the investigation of resistance reduction due to stern flap installation vary with span width and angle of installation. Based on existing research on stern flaps, the recommended chord length is $1 \%$ to $2.5 \%$ of LPP. The recommended span width of $2.5 \%$ LPP whilst vary with span width and angle of installation respectively by $50 \% \mathrm{BT}$ and $100 \% \mathrm{BT}$ and $0^{\circ}$ and $5^{\circ}$. Table 2 outlines the stern flap design variation corresponds to Figure 3.

D. Analysis of Total Resistance and Flow Forms at Various Ship Speeds

Various simulations at different ship speeds were carried out employing the model with stern flap using NUMECA Fine Marine software. Three speed variations were chosen viz. 10 knots, 13 knots and 20 knots. Finally, the total resistance and flow form resulted from the simulation were analysed and compared with the initial value and condition prior to installation of the stern flap.

\section{RESULTS AND DISCUSSION}

Numerical simulations on patrol boat model have been performed without and with installation of stern

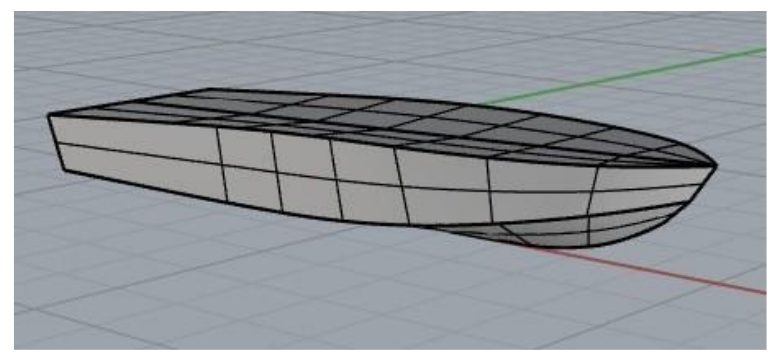

Figure. 2. Solid 3D ship model.

according to the transom width (BT, Breadth Transom) may use full width i.e. $100 \%$ BT, $75 \%$ BT, up to $50 \%$ BT. Previous research suggested that the longer and wider the size of the stern flap, the greater reduction in the value of the resistance [6]. Based on the finding, the research designed the stern flap to possess a chord length flap using NUMECA software. The simulation involved four stern flap designs run at three selected ship speeds. The resistance and stern wave formed due to installation of the stern flap have been profiled and analysed in contrast to the initial model without the flap.

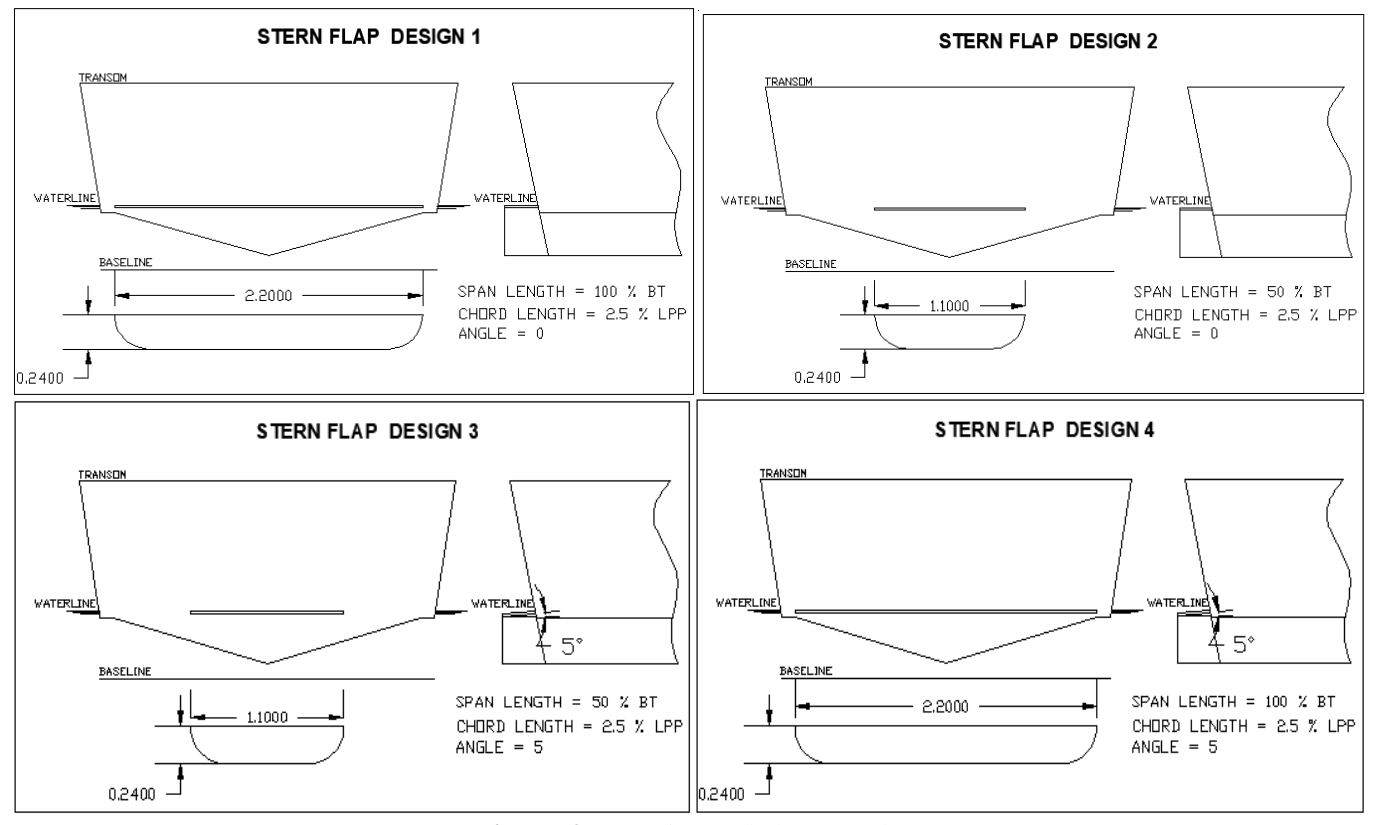

Figure. 3. Stern flap variation models. 
International Journal of Marine Engineering Innovation and Research, Vol. 5(2), Jun. 2020. 122-129

(pISSN: 2541-5972, eISSN: 2548-1479)

TABLE 2.

STERN FLAP DESIGN VARIATIONS

\begin{tabular}{cccccc}
\hline Model No & $\begin{array}{c}\text { Wide } \\
(\% \mathrm{BT})\end{array}$ & $\begin{array}{c}\text { Width of Span } \\
(\mathrm{m})\end{array}$ & \multicolumn{2}{c}{$\begin{array}{c}\text { Length of Chord } \\
(\% \text { LPP, })\end{array}$} & $\begin{array}{c}\text { Angle of installation } \\
\left({ }^{\circ}\right)\end{array}$ \\
\hline Design 1 & $100 \%$ & 2,2 & $2.5 \%$ LPP & 0,24 & 0 \\
Design 2 & $50 \%$ & 1,1 & $2.5 \%$ LPP & 0,24 & 0 \\
Design 3 & $50 \%$ & 1,1 & $2,5 \%$ LPP & 0,24 & 5 \\
Design 4 & $100 \%$ & 2,1 & $2,5 \%$ LPP & 0,24 & 5 \\
\hline
\end{tabular}

\section{A. Resistance Profiles}

Table 3 provides resistance value of the patrol boat obtained using Maxsurf and NUMECA Fine Marine. Correspondingly, Table 4 summarises the simulated resistance values of the model fitted with the four stern flaps designed. Figure 4 profiles the resistance of both models i.e. without and with stern flaps. Resistance profile of each design have been analysed against the original patrol boat model for evaluation of resistance reduction behaviour.

1) Resistance of Patrol Boat Model (Barehull) As summarised in Table 3, resistance profile of the patrol boat model obtained from Maxsurf possesses higher values than the NUMECA Fine Marine profile. However, both profiles show similar trends such that the values increase correspondingly with the ship speed. Despite higher values, the increase rate of the simulated resistance using Maxsurf is lower as compared to NUMECA which respectively values 0.14 and 0.18 .

2) Resistance of Patrol Boat Model without and with Stern Flap 2 (50\% BT and $0^{0}$ installation angle) Resistance of the patrol boat model with stern flap1 decreases in the value. The value of decrease in resistance at 10 knot is 0.158 , at a speed of $13 \mathrm{knot}$ at 0.005 , and at a speed $15 \mathrm{knot}$ the resistance value decreases by 0.010 . Percentage decrease in resistance value on flap 1, the higher speed value, the smaller percentage reduction in resistance. This means that due to the addition of the stern flap on the stern of the vessel the resistance value becomes smaller, and the performance of the stern flaps can reduce the greatest resistance at a speed of 10 knot. In previous studies (Abriansya, 2018) the greater speed, the greater the percentage of resistance reduction. However, resistance from simulation model stern flap 1, the higher speed, the smaller the value of the reduction in resistance. This can be due to the lack of fineness of the model when meshing the software.

3) Resistance of Patrol Boat Model without and with Stern Flap 2 (50\% BT and $0^{0}$ installation angle) Resistance of the model with stern flap 2 also decreases in the value. The resistance decreases at a speed of 10 knot at 0.031 , at a speed of 13 knots at 0.04 , and at a speed of 15 knots the resistance value decrease by 0.071 . The percentage decrease in the value of resistance on flap 2, the higher the speed value, the greater percentage reduction in the value of the resistance. This means that due to the addition of the stern flap on the stern of the vessel the resistance value becomes smaller, and the performance of the stern flap can reduce the greatest resistance at a speed of 15 knots. In the previous study (Abriansyah, 2018) the greater speed, the greater percentage reduction in resistance value. This decrease in resistance is very good, because from the speed of 10 knot the ship has experienced a decrease in resistance and an increase in the percentage reduction in resistance to a speed of 15 knots. This means that due to the stern flap on the stern of the ship the resistance value will be reduced.

TABLE 3.

RESISTANCE PROFILE OF THE PATROL BOAT

\begin{tabular}{cccc}
\hline $\begin{array}{c}\text { Speed } \\
(\text { Knot })\end{array}$ & Froude Number & $\begin{array}{r}\text { Resistance }- \text { Maxsurf } \\
(\mathrm{kN})\end{array}$ & $\begin{array}{c}\text { Resistance }- \text { NUMECA Fine Marine } \\
(\mathrm{kN})\end{array}$ \\
\hline 10 & 0.5190 & 4.09 & 2.86 \\
13 & 0.6746 & 4.64 & 3.54 \\
15 & 0.7784 & 4.77 & 3.80 \\
\hline
\end{tabular}

TABLE 4.

SHIP RESISTANCE WITHOUT AND WITH STERN FLAP

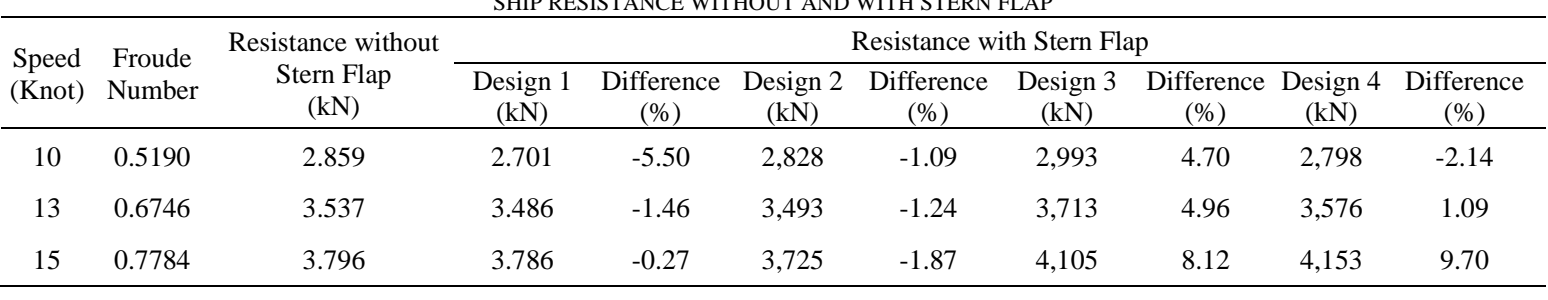




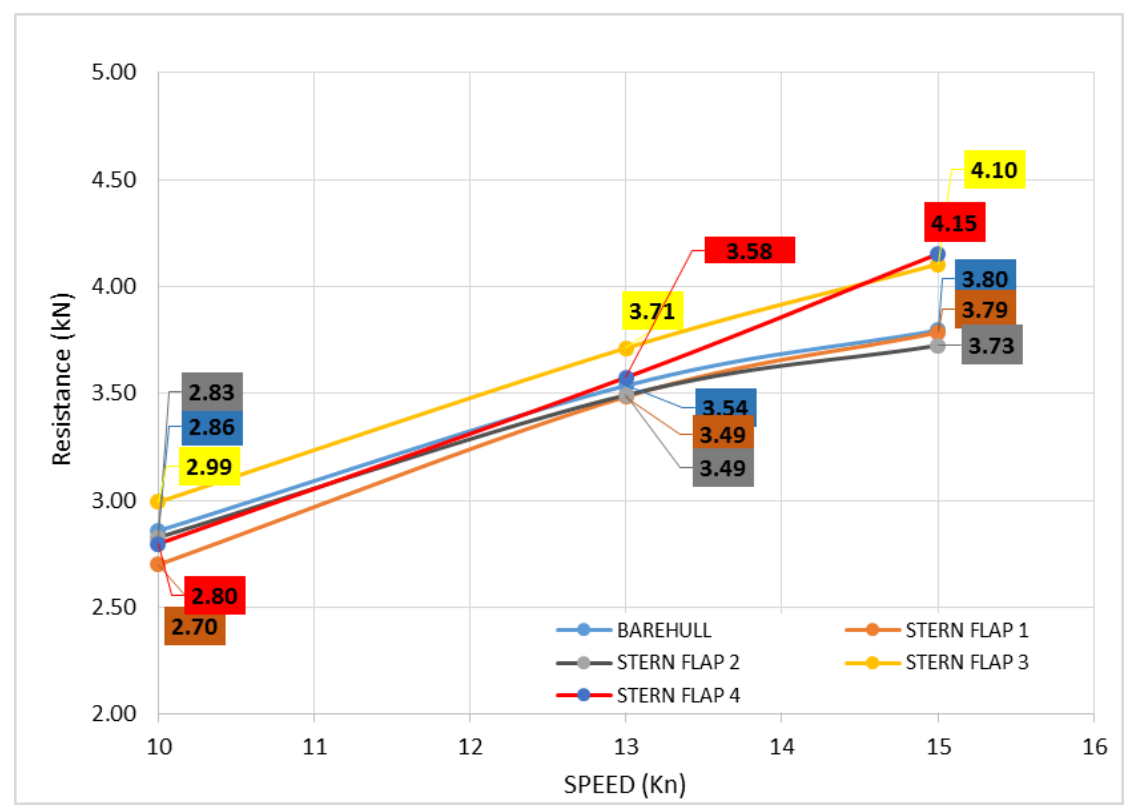

Figure. 4. Ship resistance with and without stern flap (barehull).

Stern Flap 3 (50\% BT and $5^{0}$ installation angle) Different from two previous models, the resistance of the patrol boat model employing stern flap 3 increases in the values. The value of the increase resistance at a speed 10 knot is 0.134 at a speed of 13 knots increase in resistance value is 0.18 and at a speed 15 knots increase resistance is 0.308 . Percentage increase in resistance on flap 3 , the higher speed value, the greater percentage value of the increase in resistance. This means that due to the stern flap at ana angle $5^{0}$ at the stern of the ship, the resistance value becomes greater, and the performance of the stern flap at an angle of $5^{0}$ cannot reduce the resistance, but becomes an additional resistance. According to (Abriansyah, 2018) if the angle is too deep, then the angle will be a barrier on the vessel. As happens in the stern flap model 3 with an angle of $5^{0}$. A good stern flap, the greater the speed, the greater value of the resistance. However, in the stern flap 3 applies the opposite, so it can be said that the stern flap 3 is not optimum for use.

5) Resistance of Barehull and Stern Flap 4 (100\% BT and $5^{\circ}$ installation angle)

The patrol boat model using stern flap 4 possesses different resistance profile as compared to the rest designs. The value fluctuates as the ship speed gets higher. Decrease in resistance value occurs at knots the resistance increases by 1.09 , and at a speed of 15 knots there is an increase in resistance of 0.367 which means that with the installation of the stern flap model 4 on the stern the resistance becomes greater along with increasing ship speed, and decreases with decreasing speed of ship. The performance of the stern flap will reduce the resistance at a speed of 10 knots or below the speed of 10 knots. At speeds above 10 knots, 13 knots, and 15 knots the stern flap performance does not reduce resistance, but becomes an additional resistance. Same with stern flap 3 where there is an increase in resistance along with the increase in speed on the ship. The inner angle will make the resistance on the ship. A good or optimum stern flap is used, the greater the speed, the greater the value of the resistance. However, on the stern flap 4 applies the opposite, so that it can be said that the model stern flap 4 is not optimum to use in patrol ship $10 \mathrm{~m}$

\section{B. Correctness of the model}

Verification of the patrol boat model have been check by contrasting resistance values from Maxsurf and NUMECA Fine Marine obtained previously. It can be seen from Table 5 that difference between both resistance values at all running speeds is less than $8 \%$. Adopting the statistical criteria for judging significance of important levels, the value implies that the research is

TABLE 5 .

RESISTANCE PROFILE OF THE PATROL BOAT

\begin{tabular}{ccccc}
\hline $\begin{array}{c}\text { Speed } \\
(\text { Knot })\end{array}$ & Froude Number & $\begin{array}{c}\text { Resistance }- \text { Maxsurf } \\
(\mathrm{kN})\end{array}$ & $\begin{array}{c}\text { Resistance }- \text { NUMECA Fine Marine } \\
(\mathrm{kN})\end{array}$ & $\begin{array}{c}\text { Difference } \\
(\%)\end{array}$ \\
\hline 10 & 0.5190 & 4.09 & 2.86 & 6.97 \\
13 & 0.6746 & 4.64 & 3.54 & 7.60 \\
15 & 0.7784 & 4.77 & 3.80 & 7.90 \\
\hline
\end{tabular}


$92 \%$ confidence that the model produced is correct.

\section{The Most Optimum Stern Flap Design}

The difference in the value of the resistance defines the most optimal stern flap. The value of the resistance that occurs due to the addition of a stern flap on several stern flap models made with different BT width, and with a variation of the angle $0^{0}$ and also the angle $5^{0}$ can be compares with the difference in the value of the resistance that occurs in the model that has not been given a stern flap, and with the model given the stern flap, and with the model given the stern flap is shown in a graph. From the graph above it can be concluded that the most optimum stern flap model, which can reduce resistance is the stern flap 2 model with a width of $50 \%$ BT angle $0^{0}$. In the stern flap model 2 resistance can be reduce at speeds of 10 knots to 15 knots. In addition, the reduction in the resistance value is greater with the increase in the speed of the ship, so that if the ship goes at a faster speed, then the reduction in the value of the resistance will be even greater. So the resistance on the ship will be smaller. This means that the resistance can be reduced by the addition of length on the stern of the ship at an angle $0^{0}$. If the angle is too deep, then the angle will add the resistance on the ship, such as the stern flap model 3, and the stern flap model 4.

\section{Stern Wave Profiles}

It is evident that installation of stern flap changes the transom wave system. The research further investigates the phenomena using NUMECA software. Simulations to observe the flow patterns and waveforms of the original patrol boat model and the modified ones due to the speeding vessel and installation of stern flap have been performed. All simulations were executed at 15 knot ship speed to ease the observation of the stern wave formed.

1) Stern Wave of Patrol Boat Model

Figure 5 displays the stern wave pattern of the patrol boat without installation of stern flap. As seen from the figure, the flow pattern of the patrol boat model that passes through the stern creates a whirlpool or turbulent flow. It is expected that the installation of a stern flap changes the flow patterns hence reducing the ship resistance.

2) Stern Wave of Patrol Boat Model with Stern Flap Installation

Figure 6 to Figure 9 respectively show the stern wave pattern of the patrol boat fitted with stern flap 1 to stern flap 4. Generally, the flow pattern behind the ship is elongated after the installation of stern flap. The waveform is changed from previous wave density of the initial model without the flap such that the waveform becomes wider. This may occur due to the flow pattern which is changed in direction by stern flap installed. Certainly, different design creates different profile. As comparison, the wave formed by stern flap 1 at a speed of 15 knots is wider that the wave formed by the stern flap 2 at the same speed. This may occur due to stern flap 1 having a

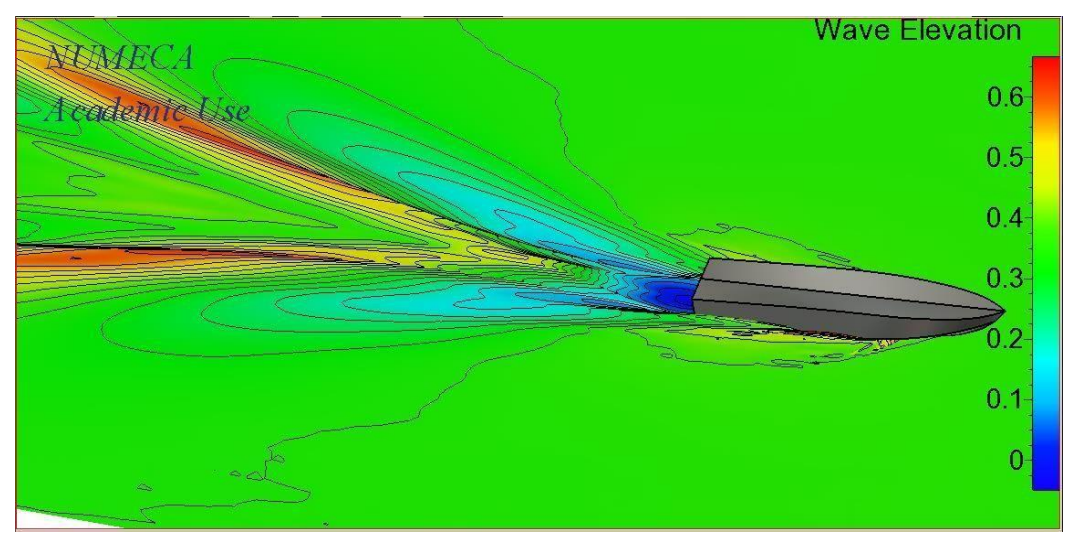

Figure. 5. Wave form of the patrol boat without stern flap.

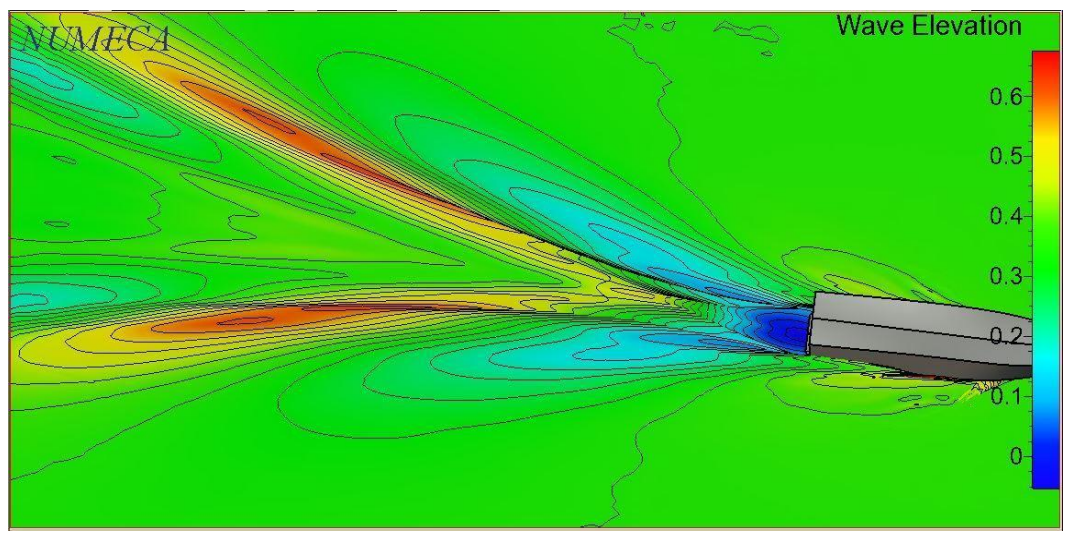

Figure. 6. Wave form of the patrol boat stern flap 1 . 


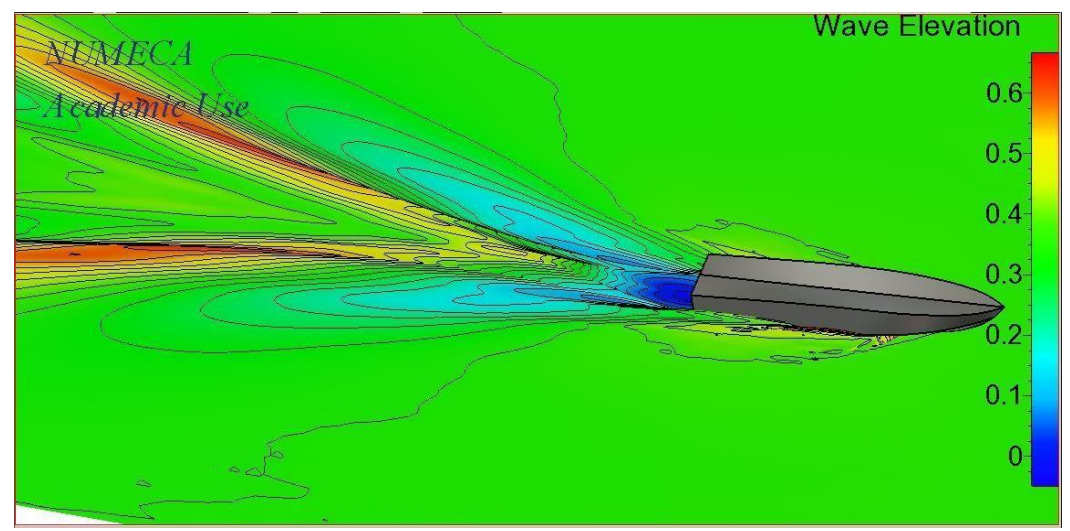

Figure. 7. Wave form of the patrol boat without stern flap.

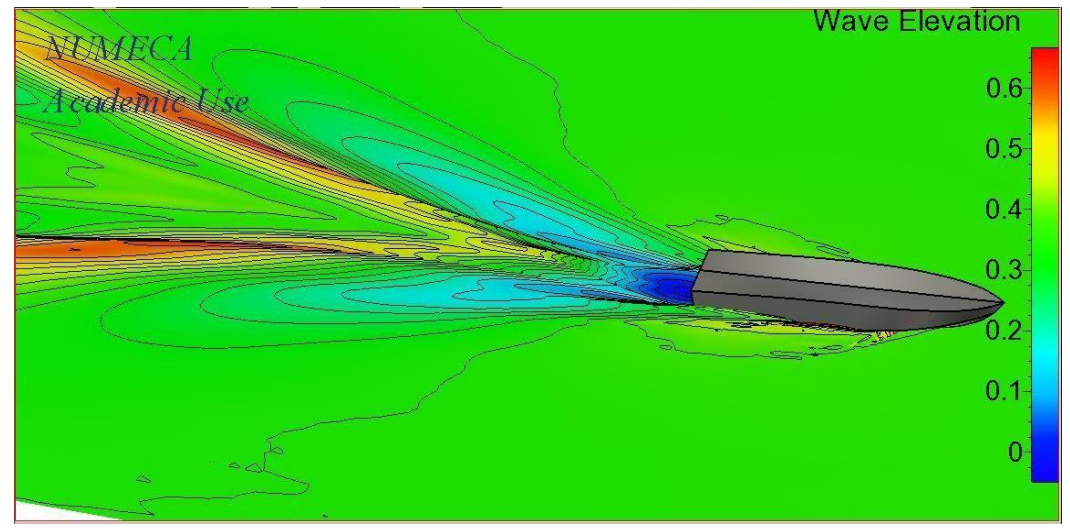

Figure. 8. Wave form of the patrol boat without stern flap.

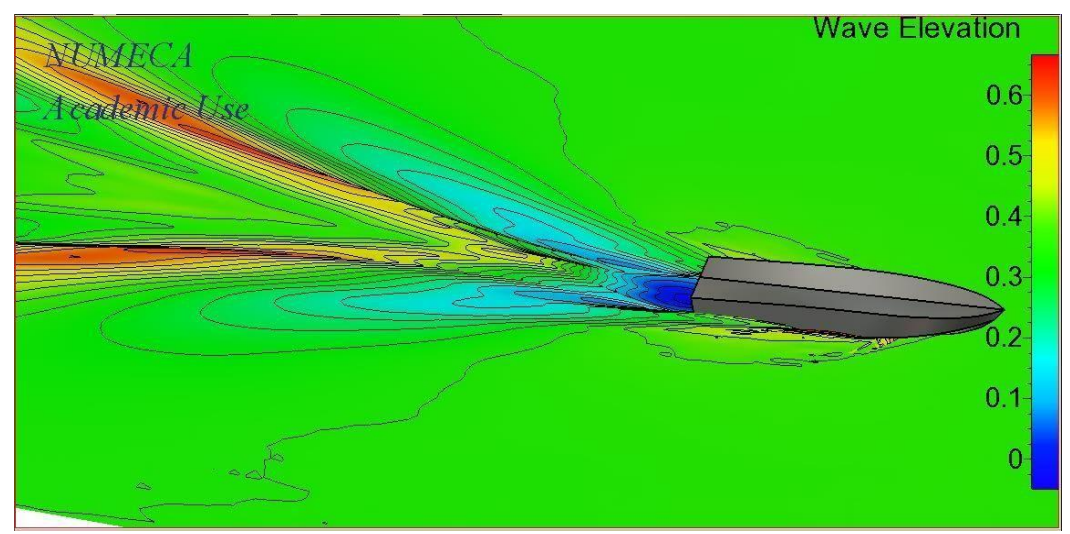

Figure. 9. Wave form of the patrol boat without stern flap.

pattern formed and flow direction follow the size of the stern flap. On the other hand, the wave formed by stern flap 1 at the speed of 15 knots is wider than the wave formed by stern flap 3 at the same speed. It may due to the stern flap 1 having a larger width as compared to the stern flap 3. As such, the flow pattern formed and flow direction follow the size of the stern flap. Summarily, the wider the size of the stern flap, the wider the wave density. For stern flap 3, the flow pattern created results in a high lift force on the back of the ship whilst quite high waves present in the front of the ship. The wave formed by stern flap 3 flap 4 for the same speed. As a common rule, the wider the size of the stern flap will create wider wave density.

\section{CONCLUSION}

Based on the simulation results on patrol boat performance without and with stern flaps, highlights are given as follows.

1) The influence of the addition of the stern flap on 
the resistance value, that with the addition of the stern flap the value of the resistance becomes reduced with increasing speed of the ship, and the difference in the reduction in the value of prisoners increases with increasing speed. This happens on ship with a stern flap 2 model with a size of $50 \%$ BT at $0^{0}$ installation angle.

2) Simulation results show that with the addition of a stern flap on the stern of the ship it can change the pattern of water flow around the stern of the ship.

\section{REFERENCES}

[1] Tampier, Gonzalo. 2013. Assesment of Appendage Effect on Forward Resistance Reduction. Ship Science \&Technology, Columbia.

[2] Fabian, Bukan. Jenis Jenis Kapal Lut Berdasarkan Fungsinya,(online),https://bukanfabianmr.wordpress.com/2014/12/ 01/jenis-jenis-kapallaut-berdasarkan-fungsinya/, diakses 4 Februari 2019

[3] Novan M. 2011. Analisa Pengaruh Penambahan Stern Flap Pada Kapal Planing Hull Dalam Usaha MengurangiTahananKapal.https://nvenggcom.blogspot.com/2017/ 04/apa-itu-cfd-computational-fluid-dynamic.html. Diakses 20 Januari 2019.

[4] Maulana Aktivano (2018). Analisa Penambahan Stern Flap Pada Kapal Hull Planing Chine Axe Bow Pengaruhnya Terhadap Tahanan Kapal, SKRIPSI, Teknik Sistem Perkapalan, Fakultas Teknologi Kelautan, Institut Teknologi Sepuluh Nopember.

[5] Dimas, Angger. Aliran Laminer dan Turbulen https://anggerdimas.wordpress.com/2012/05/27/aliran-laminerdan-turbulen, diakses 20 januari 2019.

[6] Samuel dan Manik, P.2011. Analisa Froude Number Ekonomis Pada Kapal Wisata di Waduk Jatiluhur Dengan Pendekatan Computational Fluid Dynamic (Studi Kasus KM.JASATIRTA), Semarang: Jurnal Teknik Vol.32 No.3 Tahun 2011.

[7] Silaen Guntur Andre, 2008. Analisa Hambatan Kapal Trimaran Pengangkut Ikan, SKRIPSI, Teknik Perkapalan, Departemen Teknik Mesin Fakultas Teknik Universitas Indonesia.

[8] Madina, Kapitan, 2011. Pengertian Kontruksi HaluandanBuritanKapal.https://kapitanmadina.wordpress.com/201 1/10/13/pengertian-kontruksi-haluan-dan-buritan-kapal/. Diakses 15 Juli 2019.
[9] Maritime World. Kontruksi Haluan dan Buritan Bow danStern,(online),http://www.maritimeworld.web.id/2014/01/Kont ruksi-haluan-dan-buritan-bow-dan-stern.html, diakses 14 Januari 2019.

[10] Habibie Sid'qon (2015). Study For The Stern Hull In Shallow Draft Vessel To Increase Ship Performance, THESIS, Teknologi Kelautan, Fakultas Teknologi Kelautan, Institut Teknologi Sepuluh Nopember.

[11]Hidayat, Muhammad. Tahanan Kapal Metode Guldhamer, Holtrop, dan Yamagata.https://academia .edu/12084341/TahananKapal-Metode-Guldhamer-Holtrop-dan-Yamagata,diakses 20 Januari 2019.

[12]Abriansyah, Lukman Arif (2018). Perbandingan Hambatan Kapal Akibat Penambahan Stern Flaps dan Stern Wedges Pada Kapal Cepat Monohull, SKRIPSI, Teknik Sistem Perkapalan, Fakultas Teknologi Kelautan, Institut Teknologi Sepuluh Nopember.

[13]Shiju John, 2011.Hydrodinamic Performance Enchancement Using Stern Wedges, Stern Flaps and Interceptor. Naval Science \& Technological Laboratory, India.

[14]Rider, 2012. Tahanan Kapal. http://www.ridersystem.net/2012/12/tahanan-kapal.html. Diakses 15 Juli 2019.

[15]O. Yaakob, S. Shamsuddin and K. K. King, "Stern Flap For Resistance Reduction of Planing Hull Craff: A Case Study With a Fast Crew Boat Model. Jurnal Teknologi, 2004.

[16]Cusnaelli, Dominic S. 2002. Stern Flap-A Chronicle of Succes at Sea. Naval Surface Water Center.

[17]Gilang Bayu Pangestu (2018). Analisa Pengaruh Penambahan Integrated Stern Wedge-Flap Terhadap Hambatan Kapal Dengan Metode CFD, SKRIPSI, Teknik Perkapalan, Fakultas Teknik, Universitas Diponegoro

[18]Giffari. 2007. Apa itu CFD (Computational Fluid Dynamic).https://nvenggcom.blogspot.com/2017/04/apa-itu-cfdcomputational-fluid-dynamic.html. Diakses, 20 Januari 2019

[19]Ahmad, F. 2009. Computational Fluid Dynamic (CFD). Diakses Januari 2019. fauzanahmad.wordpress.com

[20]Numeca International [2014], Numeca Fine Open Manual Book, Belgium 